DOI: $10.17976 / \mathrm{jpps} / 2018.04 .02$

\title{
СТРАТЕГИЧЕСКАЯ СТАБИЛЬНОСТЬ В УСЛОВИЯХ КРИТИЧЕСКОГО ОБОСТРЕНИЯ МЕЖДУНАРОДНОЙ ОБСТАНОВКИ
}

\section{А.А. Кокошин}

КОКОШИН Андрей Афанасьевич, доктор исторических наук, профессор, академик РАН, действительный член Российской академии ракетно-артиллерийских наук, декан факультета мировой политики МГУ имени М.В. Ломоносова, Москва. Для связи с автором: dekanat@fmp.msu.ru

Кокошин А.А. Стратегическая стабильность в условиях критического обострения международной обстановки. - Полис. Политические исследования. 2018. № 4. С. 7-21. https://doi.org/10.17976/ jpps/2018.04.02

Статья поступила в редакцию: 24.04.2018. Принята к публикации: 21.05.2018

Аннотация. Статья посвящена проблемам обеспечения стратегической стабильности в условиях значительного обострения международной обстановки, особенно взаимоотношений России и США, которое произошло в последние годы. Политический курс официального Вашингтона привел к усугублению угроз прямого военного столкновения США с Россией, вплоть до возникновения ситуаций, сопоставимых по интенсивности и опасности с Карибским кризисом 1962 г. Автор акцентирует остроту проблем распространения ракетно-ядерного оружия, которое влияет и на проблему стратегического ядерного баланса между Россией и США. Обеспечение стратегической стабильности в значительной степени зависит от активного развития различных технологий и систем вооружений, в том числе связанных с киберпространством и потенциальными средствами силового противоборства в космосе. Все это заставляет говорить о серьезной эрозии стратегической стабильности. Такая эрозия происходит в условиях перехода системы мировой политики от “однополярности” к относительной “многополярности”, который совершается отнюдь не плавно. В целях эффективного анализа многомерных проблем стратегической стабильности и решения задач ее укрепления автор считает необходимым сосредоточить внимание на взаимоотношениях между Россией и США в стратегической ядерной сфере, учитывая фактор стратегической ПРО, стратегического неядерного оружия и нестратегического (тактического) ядерного оружия.

Ключевые слова: стратегическая стабильность; рост напряженности; кризисные ситуации; стратегическое ядерное сдерживание; стратегическое неядерное сдерживание; ограничение вооружений; сокращение вооружений.

Устойчивой характеристикой современного состояния системы мировой политики на протяжении ряда лет остается растущая напряженность, нестабильность и неопределенность в целом ряде ее важнейших сегментов. Истоки этой напряженности лежат прежде всего в политике США, оказавшихся после распада СССР единственной сверхдержавой и неоднократно действовавшей и ныне действующей силовыми методами в нарушение международного права, в обход Совета Безопасности ООН. Рост неопределенности подрывает основы стратегической стабильности. Прежде чем рассмотреть вопрос об интерпретации стратегической стабильности в широком и узком толковании этого термина в контексте стремительно меняющейся международной ситуации, посмотрим, как эскалация напряженности изменила окружающую реальность, какие новые тенденции стали превалировать. 


\section{ПРИЧИНЫ И ХАРАКТЕРИСТИКИ РОСТА НАПРЯЖЕННОСТИ}

Тенденция к нарастанию международной напряженности действует с некоторыми девиациями с 1990-х годов, однако в последние годы она значительно усилилась. Существенным источником дестабилизации стало расширение НАТО на Восток, распространившееся и на бывшие республики СССР - Латвию, Литву, Эстонию. Тем самым США и их союзники демонстрировали игнорирование интересов России - как политических, так и военно-стратегических.

Серьезно дестабилизировал обстановку односторонний выход администрации Дж. Буша-мл. из бессрочного советско-американского Договора об ограничении систем ПРО 13 июня 2002 г., хотя формально он и не нарушал положения документа ${ }^{1}$. Последствия этого шага долго будут сказываться негативно на отношениях между Россией и США.

Международную ситуацию обострил и “украинский кризис", источником которого стало насильственное свержение при поддержке Запада законного президента Украины В. Януковича в феврале 2014 г. За этим последовали такие важные события, как возвращение Крыма в состав России и конфронтация в Донбассе, приведшая к созданию самопровозглашенных Луганской народной республики (ЛНР) и Донецкой народной республики (ДНР). Против них Киев развязал масштабные военные действия, получившие официальное название “антитеррористической операции”.

Активное (и во многом эффективное) противодействие оказали ополчения ЛНР и ДНР при участии российских добровольцев. В итоге НАТО обвинила Россию в развязывании “гибридной войны” на Украине. Начальник Генштаба

8 Вооруженных сил РФ генерал армии В.В. Герасимов заявил о необходимости для России быть готовой “защитить интересы государства в военном конфликте любого масштаба с широким применением противником как традиционных, так и гибридных методов противоборства"2. Политика США и их союзников породила ситуацию критического дисбаланса стратегической стабильности в мире.

При рассмотрении возможных вариантов эскалации конфликтов между Россией и США и их союзниками довольно популярными в ряде исследований стали искусственные, надуманные сценарии войны между Россией и НАТО, в которых Москва первой использует - правда, в ограниченных масштабах - тактическое ядерное оружие. Запад активизировал разнообразную военную деятельность на своем восточной направлении, прежде всего в Прибалтике и в Польше, а также в акватории Черного моря. Россия вынуждена реагировать адекватным образом в политико-дипломатической и военной сфере, проводя в том числе военные учения и развивая свои группировки сил и средств, причем обе стороны неоднократно испытывали возможности своих стратегических ядерных сил.

\footnotetext{
1 Заметим, что при предшествовавшей администрации У. Клинтона Договор по ПРО признавался и Россией, и США “краеугольным камнем стратегической стабильности”. (По инициативе российской стороны на Московском саммите 9-11 мая 1995 г. это было отмечено в совместном заявлении президентов России и США Б.Н. Ельцина и У. Клинтона. Одновременно была достигнута договоренность, что системы ПРО на ТВД могут быть развернуты, но не вести к нарушению Договора, и что такие системы не должны составлять реальной угрозы для стратегических ядерных сил каждой из сторон.) [Есин 2015: 85-114].

${ }^{2}$ Герасимов В. По опыту Сирии. - Военно-промышленный курьер. 9.03.2016. № 9 (624). Доступ: http:// vpk-news.ru/articles/29579 (проверено 10.03.2018).
} 
США и их союзники по НАТО ведут против России массированную информационную и экономическую войну. Администрация Д. Трампа дважды в нарушение Устава ООН принимала решения о нанесении ракетных ударов по Сирии. При этом Вашингтон рисковал втянуться в прямое военное столкновение с Россией, что было бы чревато непредсказуемой эскалацией вплоть до ситуации, сопоставимой по остроте с Карибским кризисом.

Один из важнейших уроков Карибского кризиса состоит в том, что кризис нельзя доводить до такого уровня остроты. Видный отечественный дипломат Г.М. Корниенко с глубоким пониманием сути проблемы писал: “Первый и главный урок, вытекавший из Карибского кризиса... - не допускать возникновения подобных кризисов, чреватых пусть даже небольшой вероятностью перерастания в большую войну, не полагаться на то, что всякий раз удастся остановиться у опасной черты" [Корниенко 2001: 47]. Отсюда вытекает вывод о важности предотвращения кризисных ситуаций и обеспечения надежного управления в таких условиях.

Удары США и их союзников по Сирии 14 апреля 2018 г. подвели к выводу, что продолжение подобных действий приведет к хаосу в международных отношениях ${ }^{3}$. Практически был свернут некогда интенсивный диалог между Москвой и Вашингтоном по ограничению и сокрашению вооружений. Под угрозой находится советско-американский Договор о ликвидации ракет средней и меньшей дальности 1987 г. (ДРСМД). Туманными остаются перспективы продления после 2021 г. российско-американского Договора о сокращении стратегических наступательных вооружений 2010 г. (СНB-3).

В 2018 г. в “Обзоре ядерной политики” администрации Д. Трампа сформулированы положения, укрепляющие роль ядерного оружия в политиковоенной стратегии США, в том числе в непосредственном противостоянии с Россией и Китаем. Доктринальные положения этой политики говорят о том, что Вашингтон ведет дело к снижению порога применимости ядерного оружия 4 . В этом отношении ядерная политика администрации Д. Трампа носит более дестабилизирующий характер, чем политика предыдущей администрации Б. Обамы. В документе 2018 г. содержится немало необоснованных обвинений в адрес военной, в том числе ядерной, политики России. Относится это и к роли нестратегического (тактического) ядерного оружия в российской военной политике. В ответ С.В. Лавров заявил, что у России нет развернутого тактического ядерного оружия и что она не проводит отработку его применения. При этом министр поставил в вину США и их союзникам “дестабилизирующую практику" совместных ядерных миссий и то, что “наличие готовых к применению тактических ядерных вооружений США в Европе - не просто рудимент холодной войны, а явно агрессивная позиция" 5 .

Планы администрации Д. Трампа предполагают развитие глобальной системы ПРО США, состоящей из компонентов национальной ПРО и ПРО на театре военных действий (ТВД). После нескольких лет лоббистской

\footnotetext{
${ }^{3}$ Телефонный разговор с Президентом Ирана Хасаном Рухани. - Президент России. Официальный сайт. 15.04.2018. Доступ: http://Kremlin.ru/events/president/news/57263 (проверено 20.04.2018).

${ }^{4}$ Обзор ядерной политики. - Аппарат Министра обороны США. Официальный сайт. Февраль 2018. Доступ: https://media.defense.gov/2018/Feb/02/2001872876/-1/-1/1/EXECUTIVE-SUMMARYTRANSLATION-RUSSIAN.PDF (проверено 24.03.2018).

5 Лавров обвинил США в подготовке стран Европы к тактическому ядерному удару по России. Коммерсантв. 28.02.2018. Доступ: https://www.kommersant.ru/doc/3560233 (проверено 18.04.2018).
} 
деятельности сторонникам возрождения планов создания ПРО с элементами космического базирования ${ }^{6}$ удалось в 2016 г. добиться включения в текст закона о военном бюджете нормы, предписывающей министру обороны и Комитету начальников штабов исследовать такую возможность и представить доклад конгрессу СШАㄱ. Лоббисты этого направления в развитии ПРО США активно действуют и при администрации Д. Трампа.

Принятый в самом конце 2016 г. закон об ассигнованиях на национальную оборону на 2017 финансовый год содержал положения о радикальном пересмотре политики США в области ПРО ${ }^{8}$. Если закон 1999 г. о национальной ПРО определял ее задачу как защиту страны от "ограниченного удара баллистических ракет”, то в новом законе целью политики США объявлено поддержание и совершенствование эффективной и надежной многоуровневой противоракетной обороны, способной обеспечить защиту территории США и их союзников от меняющихся и многообразных угроз, связанных с баллистическими ракетами [подробнее см. Есин 2016: 147].

Близкие Дональду Трампу круги упрекают администрацию Обамы в том, что она перестала финансировать разработку противоракеты $S M-3$ Block IIB системы "Иджис", которая должна была стать основным средством перехвата следующего этапа развития “глобальной ПРО”, и отказывалась рассматривать вопрос о космических боевых станциях (КБС) ПРО на основе “имеющихся технологий”. Соответственно, снова поднимается вопрос о выделении средств на исследования и разработки средств перехвата космического базирования [Dodge 2017: 6]. В противовес этим рекомендациям в одном из серьезных американских исследований предлагается достичь договоренностей США с Россией и Китаем о запрещении перехватчиков космического базирования и оружия направленной энергии [Miller, Fontaine 2018: 24].

\section{РАСПОЛЗАНИЕ ОЧАГОВ ЭСКАЛАЦИИ НАПРЯЖЕННОСТИ}

Резкая дестабилизация ситуации вокруг проблемы распространения ядерного оружия обозначилась в связи с зигзагами политической конъюнктуры, связанной с усилиями Пхеньяна по созданию собственного ракетно-ядерного оружия (в том числе достигающего территории США). Еще более накалилась политическая атмосфера опасностью потенциального возврата Ирана к ядерной программе военного назначения из-за объявленного Д. Трампом выхода США из международного соглашения по ядерной программе Ирана․ Следует принять во внимание и заявления руководства Саудовской Аравии о том, что оно обязательно вслед за Ираном обретет собственное ядерное оружие. Таким образом, на нестабильном Ближнем Востоке - с учетом наличия арсенала ядерного оружия у Израиля с высокой степенью вероятности может возникнуть “ядерный треугольник".

\footnotetext{
6 Independent Working Group on Missile Defense, the Space Relationship, and the Twenty-First Century. 2009 Report. Cambridge, MA: The Institute for Foreign Policy Analysis. 2009. URL: http://www.ifpa.org/pdf/ IWG2009.pdf (accessed 24.03.2018).

7 National Defense Authorization Act for Fiscal Year 2017. 114th Congress. 970 p. URL: https://www.congress. gov/114/plaws/publ328/PLAW-114publ328.pdf (accessed 26.03.2018).

${ }^{8}$ Ibidem.

${ }^{9}$ Совместный всеобъемлющий план действий - Соглашение 15 июля 2016 г. между Ираном и странами “шестерки” (США, Франция, Великобритания, Германия, Китай, Россия).
} 
Реализация ракетно-ядерной программы КНДР, в связи с которой неоднократно принимались резолюции СБ ООН (при активной роли России и Китая), используется США для наращивания усилий в развитии как стратегической (национальной) системы ПРО, так и (совместно с такими союзниками Соединенных Штатов, как Япония и Республика Корея) ПРО на ТВД. Эти действия не могут не тревожить Россию и Китай, ибо наращивание возможностей национальной ПРО США рассматривается как фактор снижения стратегической стабильности в отношениях РФ - США, КНР США. У Москвы и Пекина много оснований для того, чтобы добиваться решения проблемы ракетно-ядерного оружия Пхеньяна переговорным путем с учетом интересов безопасности всех сторон.

Ракетная программа Ирана, которую Тегеран не стал сворачивать после своего отказа от создания ядерного оружия, послужила официальным обоснованием для размещения объектов американской системы ПРО (с использованием многофункциональной системы “Иджис Эшор") в Румынии и Польше. Москва восприняла это негативно - как шаг в направлении подрыва стратегической стабильности, в том числе как нарушение Договора о РСМД, поскольку установки обладают способностью к запуску крылатых ракет большой дальности наземного базирования, запрещенных ДРСМД.

Оценивая среднесрочные перспективы развития международной политиковоенной обстановки, не следует забывать об Индии и Пакистане - ядерных державах с 1998 г., у которых имеется затяжной территориальный спор, чреватый регулярными обострениями. При этом одновременное вступление Индии и Пакистана в Шанхайскую организацию сотрудничества позволяет надеяться, что это будет способствовать уменышению вероятности их политико-военного и военно-стратегического противостояния, имеющего и ядерное измерение.

В новом контексте роста напряженности определенную роль будут продолжать играть стратегические ядерные силы Франции и Великобритании, однозначно являющиеся “дополнением” к СЯС США. С высокой степенью вероятности следует прогнозировать возрастание значения стратегических ядерных сил КНР. Остаются значительными масштабы деятельности международных террористических организаций, несмотря на поражение запрещенного в России “Исламского государства" в Сирии и Ираке. Попрежнему существует угроза появления у террористов ядерного оружия. В условиях эскалации напряженности в отношениях РФ - США, РФ НАТО характер и масштабы сотрудничества по борьбе с терроризмом явно не отвечают потребностям международного сообщества.

Наряду с негативными тенденциями в международной обстановке происходит быстрое развитие комплекса технологий и систем вооружений, непосредственно влияющих на стратегическую стабильность [Веселов 2015: 23-56]. Это относится и к инновациям, повышающим точность боевых блоков американских СЯС. Так, в американских источниках появились сведения о резком наращивании “контрсилового потенциала” морской составляющей американских СЯС за счет повышения точности подавляющей части боевых блоков БРПЛ “Трайдент-II" (W76-1/MK4A и W88/MK5) с отрицательными последствиями для стратегической стабильности, отмечаемыми авторитетными американскими учеными [Kristensen, McKinzey, Postal 2017].

Наряду со сравнительно традиционными технологиями и системами на стратегическую стабильность заметное воздействие оказывают 
инновационные изменения в области киберпространства, форм и способов ведения “боевых киберопераций”. Немаловажную роль играет и развитие Соединенными Штатами потенциальных средств военного противоборства в космосе, в том числе "роевых группировок" - как для противоспутникового, так и противоракетного оружия.

Все это происходит в условиях стремительной трансформации структуры мировой политики, сокращения роли и веса США, их союзников по НАТО, ЕС в мировых делах, возрастания значения стран Индо-Тихоокеанского региона и прежде всего КНР. Последняя, обойдя в 2014 г. США по объему ВВП (ППС), претендует в обозримой перспективе на роль “второй сверхдержавы", обретая не только экономические и политические возможности, но и значительную военную мощь.

Очевидно, что “плавный переход” от “однополярности” к более децентрализованной системе мировой политики с соответствующей адаптацией к ее реальностям Соединенных Штатов не состоялся. Формирующаяся относительная "многополярная" система мировой политики пока остается весьма неустойчивой. Необходимы немалые усилия для обеспечения управляемости нарождающейся системы, выхода ее из состояния нарастающей хаотичности, о которой говорит В. Путин. Среди них едва ли не главную роль должны играть переговоры и меры по обеспечению стратегической стабильности.

Вашингтон прилагает большие усилия для сохранения своего "лидерства" в мире, для ограничения возможностей тех государств, которые, по его мнению, в наибольшей мере препятствуют этому, для их “сдерживания". И такими государствами, по мнению подавляющей части политического класса США, являются прежде всего Россия и Китай, в возможностях каждого из которых имеется своя специфика. РФ, уступая значительно и США, и Китаю по своему ВВП, экономическим возможностям, остается сверхдержавой по ракетно-ядерному параметру военной мощи, в последние годы еще больше укрепила свои позиции. Одной из демонстраций этого стали новые системы вооружений, о которых заявил президент России в Послании Федеральному Собранию 1 марта 2018 г. ${ }^{10}$ Соответственно, важнейшую роль с точки зрения глобальной стратегической стабильности продолжает играть “центральный ядерный баланс" Россия - США.

Россией и КНР далеко не исчерпывается перечень государств, которых не устраивал тот миропорядок, который пытались сформировать США после распада СССР. Многие государства демонстрировали и демонстрируют стремление к более справедливому режиму функционирования системы мировой политики. Но они не обладают теми возможностями, которые имеются у России и КНР.

Взаимоотношения Москвы и Пекина носят особый характер и определяются формулой “отношений всеобъемлющего равноправного доверительного партнерства и стратегического взаимодействия, взаимной поддержки, совместного процветания и дружбы, передающейся из поколения в поколение". ${ }^{\prime}$ С КНР складываются по ряду направлений фактически квазисоюзнические отношения: интенсивные контакты на высшем уровне и на уровне руководителей

\footnotetext{
${ }^{10}$ Послание Президента Федеральному Собранию. - Президент России. Официальный сайт. 01.03.2018. Доступ: http://kremlin.ru/events/president/news/56957 (проверено 24.04.2018).

${ }^{11}$ Совместное заявление Российской Федерации и Китайской Народной Республики. - Президент России. Официальный сайт. 25.06.2016. Доступ: http://kremlin.ru/supplement/5100/print (проверено 24.04.2018).
} 
военных ведомств, целого ряда структур Министерства обороны РФ и Центрального военного совета КНР; масштабные совместные военные учения российских Вооруженных сил и Народно-освободительной армии Китая (НОАК) в различных районах мира (в том числе чувствительных с точки зрения обеспечения стратегической стабильности на потенциальных ТВД).

25 июня 2016 г. лидерами России и КНР был подписан узловой политический документ, на основе которого можно работать по этой теме применительно к военному планированию, к решению оперативностратегических вопросов $^{12}$. Неоднократно Генштабом Вооруженных сил РФ и Объединенным штабом НОАК рассматривались вопросы противоракетной обороны (в связи с деятельностью США в этой сфере), проводилось совместное компьютерное моделирование соответствующих процессов. КНР поддерживает в совместных учениях Россию в Евроатлантическом регионе, а РФ поддерживает КНР применительно к обстановке в районе ЮжноКитайского моря и Восточно-Китайского моря.

При этом не следует недоучитывать наличие несовпадающих и даже конфликтных интересов у России и Китая. Кроме того, экономическая составляющая отношений РФ - КНР значительно отстает в своем развитии от политической и политико-военной. Именно Россию и КНР администрация Д. Трампа обвиняет в том, что они добиваются изменения миропорядка, “бросают вызов американской мощи, влиянию и интересам"13.

\section{ПОНЯТИЕ “СТРАТЕГИЧЕСКАЯ СТАБИЛЬНОСТЬ”: ШИРОКАЯ И УЗКАЯ ИНТЕРПРЕТАЦИИ ТЕРМИНА}

Стратегическая стабильность - многомерная междисциплинарная тема, требующая разработки специалистами по политико-дипломатическим, политикопсихологическим, военно-стратегическим, военно-техническим и другим проблемам. При этом, как справедливо отметили А.Г. Арбатов и В.3. Дворкин, математические модели стратегической стабильности “вряд ли можно назвать универсальным инструментом”, поскольку “слишком много факторов, не укладывающихся в математические формулы, оказывают влияние на эти процессы” [Арбатов, Дворкин 2011: 3-11].

С учетом новой политико-военной обстановки, развития технологий и систем вооружений важно сосредоточить внимание на условно узкой трактовке понятия “стратегическая стабильность", которая в первую очередь предполагает определенное состояние взаимодействия России и США в стратегической ядерной сфере с учетом, разумеется, фактора стратегической ПРО и стратегического неядерного оружия, а также нестратегического (тактического) ядерного оружия (НСЯО). Понятие “стратегическая стабильность” применимо и к взаимодействию сторон в силах и средствах общего назначения (обычных вооружений).

Проблемы стратегической стабильности до распада СССР рассматривались преимущественно применительно к взаимоотношениям между ОВД и НАТО в Европе. Утверждая мандат переговоров по обычным вооружениям

\footnotetext{
12 Совместное заявление Президента Российской Федерации и Председателя Китайской Народной Республики об укреплении глобальной стратегической стабильности. - Президент России. Официальный сайт. 25.06.2016. Доступ: http://kremlin.ru/supplement/5098 (проверено 24.04.2018).

13 National Security Strategy of United States of America. 2017. P. 2. URL: https://www.hsdl. org/?view\&did=806478 (accessed 24.04.2018).
} 
и вооруженным силам в Европе, представители 23 государств - членов НАТО и ОВД решили, что их цель - “укрепление стабильности и безопасности в Европе путем установления стабильного и безопасного баланса обычных вооруженных сил, которые включают обычные вооружения и технику, на более низких уровнях; ликвидации неравенств, наносящих ущерб стабильности и безопасности; и ликвидации, в порядке приоритета, потенциала для осуществления внезапного нападения и для начала крупномасштабных наступательных действии"14.

В СССР велась интенсивная разработка оборонительной военной доктрины, которая, как отмечал маршал С.Ф. Ахромеев, предусматривала, что "в случае агрессии против нас" (НАТО во главе с США) нападение на ОВД будет отражаться на определенный период времени "только оборонительными операциями”, что сочеталось бы с политическими усилиями по ликвидации конфликта [Ахромеев, Корниенко 1992: 126].

На Западе (особенно в ФРГ и Нидерландах) применительно к военнодоктринальным установкам НАТО и к ее оперативно-стратегическому и военнотехническому обеспечению разрабатывались концепции "ненаступательной обороны” и “оборонительной обороны”. В значительной мере такие концепции предназначались для регламентации использования тактического ядерного оружия США и НАТО на ранней стадии военных действий в случае успешного наступления сил ОВД на центральном участке противостояния НАТО и ОВД (в Германии) - особенно в районе так называемого Фульдского прохода (или “коридора") ${ }^{15}$. С советской стороны разрабатывались формулы контрнаступательной обороны, в том числе на основе "модели Курской битвы” 1943 г. [Кокошин, Ларионов 1987: 15-21].

В 1980-е годы речь шла исключительно об Атлантическом регионе, о взаимодействии Организации Варшавского Договора и НАТО. Сейчас, на перспективу пять-десять и более лет, речь снова идет об этом регионе, а также о некоторых сегментах гигантского Индо-Тихоокеанского региона, прежде всего о зонах, прилегающих к территории КНР. Тема стратегической стабильности применительно к соответствующим районам этого мегарегиона должна рассматриваться предметно. Очевидно, что в КНР и в США она привлекает внимание, в том числе с учетом фактора ПРО на ТВД и потенциальных американских средств “неядерного быстрого глобального удара” (НБГУ) для поражения позиций китайских баллистических ракет в неядерном снаряжении, аэродромов, баз ВМС на ТВД, наращивания собственных возможностей НОАК по обеспечению “победы в локальной информационной войне" ${ }^{16}$ и др.

При этом надо иметь ввиду, что существует и более широкая интерпретация стратегической стабильности, предполагающая фактически рассмотрение вопросов положения дел в системе мировой политики, в различных сегментах

\footnotetext{
${ }^{14}$ Итоговый документ Венской встречи 1986 года представителей государств - участников Совещания по безопасности и сотрудничеству в Европе, состоявшейся на основе положений Заключительного акта, относящихся к дальнейшим шагам после Совещания. Вена, 19 января 1989 г. Приложение III. Мандат переговоров по обычным вооруженным силам в Европе. С. 46-55. Доступ: https://www.osce. org/ru/mc/40885?download=true (проверено 02.03.2018).

15 От границы с ГДР до Франкфурта-на-Майне наступающим через Фульдский коридор (земля Гессен) советским войскам надо было бы преодолеть лишь 100 км. - Фульдский коридор: Фермопилы холодной войны. Часть 1. - Только война. Доступ: http://war-only.com/fuldskij-koridor-fermopilyxolodnoj-vojny-chast-1.html (проверено 28.03.2018)

${ }^{16}$ Военный атташе: Китай придерживается стратегии активной обороны. - TACC. 08.12.2017. Доступ: http://tass.ru/opinions/interviews/4792302 (проверено 02.06.2018).
} 
этой системы. Такая интерпретация, безусловно, имеет право на существование. Однако в нынешних сложнейших условиях продуктивное рассмотрение Россией и Соединенными Штатами широкой повестки дня (фактически связанной с динамикой изменений миропорядка) представляется весьма затруднительным. Это связано не только с конкретными разногласиями между РФ и США по проблемам международной безопасности, по оценкам обстановки в регионах мира, но с тем, что для России неприемлем тот миропорядок, который выстраивали США после завершения холодной войны и распада СССР.

Стратегическую стабильность можно рассматривать как обеспечение политико-военных, оперативно-стратегических и военно-технических условий, минимизирующих опасность возникновения конфликтных и кризисных ситуаций, которые могли бы поставить вопрос о военных действиях с применением ядерного оружия.

В основе стратегической стабильности в ее стратегическом ядерном измерении лежит неспособность каждой из сторон нанести упреждающий удар (или удар в назначаемое время), способный вывести из строя если не все, то подавляющую часть ядерных сил и средств другой стороны, которые могут быть использованы в ответном ударе возмездия. Стабильной ситуация считается тогда, когда страна-агрессор не может прикрыться своими средствами противоракетной обороны (ПРО) от ответного удара возмездия (наносящего “неприемлемый” ущерб) стороны, подвергшейся нападению.

Для российских СЯС это сочетание неуязвимости, высокой степени выживаемости всех трех компонентов сил и средств сдерживания со способностью преодолевать ПРО противника. То есть речь идет о невозможности обеспечения обезоруживающего "первого" удара американскими ядерными и неядерными средствами по российским СЯС с нейтрализацией ответного удара со стороны СЯС России средствами национальной (стратегической) ПРО США.

Стратегическая стабильность для Москвы предполагает надежность, убедительность обеспечения стратегического ядерного и неядерного сдерживания с должным политико-психологическим воздействием на “оппонента". В центре убедительного ядерного сдерживания была и остается демонстрация способности при любых, самых неблагоприятных условиях нанести ответный удар возмездия с катастрофическими последствиями для агрессора. Возможности России по реализации ядерного и неядерного сдерживания в последние годы значительно возросли, в отличие от тяжелейших для страны 1990-х годов. Это относится к вводу в строй компонентов СЯС наземного, морского и воздушного базирования с использованием научно-технических заделов 1980-х, 1990-х годов и последующего периода. Повышается боевая устойчивость (неуязвимость) ракетных войск стратегического назначения (РВСН) и морских стратегических ядерных сил, способность межконтинентальных баллистических ракет (МБР) и баллистических ракет подводных лодок (БРПЛ) к преодолению перспективных систем ПРО вероятного противника. Значимые результаты достигнуты в развитии системы предупреждения о ракетном нападении (СПРН), системы контроля космического пространства (СККП), системы боевого управления (СБУ) СЯС. Немаловажные результаты получены и в развитии компонентов стратегической ПРО, а также средств ПВО, обладающих определенными противоракетными возможностями.

Россия успешно демонстрирует многие достижения таким образом, чтобы они фиксировались другой стороной. Это относится к учебным пускам 
МБР “Тополь” и “Тополь-М”, “Ярс”, БРПЛ “Синева” и “Булава”, учениям $\mathrm{PBCH}$, полетам бомбардировщиков стратегической авиации, испытательным пускам тяжелой МБР “Сармат” и др. Тем самым обеспечивается политикопсихологический эффект ядерного сдерживания.

Стратегическая стабильность предполагает полную подконтрольность всех средств поражения высшему государственному руководству и военному командованию в целях предотвращения случайного и несанкционированного использования ядерного оружия (начиная с тактического). Это в том числе предусматривает надежную защиту от кибератак противника (или какой-либо третьей стороны), систем боевого управления, сохранение в руках высшего руководства всей полноты власти для принятия решений на ответные действия на основе объективных, надежных данных системы предупреждения о ракетном нападении (СПРН), которая состоит из двух эшелонов - космического и наземного. Первый - орбитальная группировка космических аппаратов обнаружения стартов баллистических ракет на высокоэллиптических и геостационарных орбитах. Главный компонент наземного эшелона СПРН - радиолокационные станции дальнего обнаружения, причем "вклад первого (космического) и второго (наземного) эшелонов одинаково важен” [Нестерчук, Аксенов 2017: 45]. По сигналам, поступающим от первого, должны приниматься предварительные решения по ответным действиям стратегических ядерных сил. Космический эшелон СПРН дает возможность существенно увеличивать время предупреждения о ракетном нападении и снижать уровень ложных тревог. По информации второго, наземного, эшелона принимаются окончательные решения о масштабе и способах применения СЯС [там же: 49].

\section{ЧТО ПОКАЗАЛИ ИССЛЕДОВАНИЯ АМЕРИКАНСКИХ УЧЕНЫХ}

Исследования американских ученых, в частности, из Ратгерского университета, свидетельствуют о потенциальных катастрофических последствиях для климата и агропроизводства в мире в виде массового голода после применения всего лишь 1\% от накопленных ядерных арсеналов [Mills, Toon, Lee-Taylor, Robock 2014: 161-176; Robock, Toon 2012: 66-74; Robock, Oman, Stenchikov 2007: 1-14].

В докладе исследовательского центра RAND, тесно связанного с военным ведомством США, отмечается, что “стратегические ядерные отношения" между Соединенными Штатами и Россией остаются наиболее важными; две ядерные сверхдержавы “обладают способностью осуществить широкомасштабные, скоординированные ядерные удары, которые могут уничтожить целые континенты" [Chivvis et al. 2017: 1]. Возросла "вероятность стратегического ядерного обмена" из-за ухудшения отношений и “эскалационных рисков” [ibid: 1-2]. Отмечается, что “Соединенные Штаты и Россия по-прежнему имеют 'глубокие общие интересы', чтобы избежать ядерной войны. Но 'значимый прогресс' в обеспечении стратегической стабильности 'потребует мужества и жертв с обеих сторон"' [ibid.: 11].

Политологи Дж. Миллер и Р. Фонтейн пишут о том, что “на протяжении десятилетий стабильность американо-российского баланса основывалась на твердом понимании того, что у обеих сторон имелись гарантированные возможности для второго (ответного - nрим. A.K.) удара", причем “ни одна из сторон не могла бы с реалистической точки зрения нанести разоружающий первый удар по ядерным силам другой стороны”. Но “поставить эту уверенность под сомнение" может развитие ряда военных технологий, интегрируемых в военную политику [Miller, Fontaine 2017: 6]. 
В последние 10-12 лет появились сценарии нанесения внезапного “обезоруживающего" удара США по стратегическим ядерным силам России (и КНР) с применением как ядерных, так и неядерных средств поражения. Такой “обезоруживающий” удар отражает гипотетические возможности разведки и целеуказания, которых не было еще 15-20 лет назад, а также боевых киберопераций, особенно связанных с системами предупреждения о ракетном нападении и системами боевого управления СЯС России.

Кейр Либер, доцент Школы дипломатической службы им. Э. Уолша Джорджтаунского университета, и Дэрил Пресс, доцент факультета управления Дартмутского колледжа, указывают на возможности сбора информации от различных источников, увеличивающих вероятность определения точного местоположения мобильных пусковых установок МБР и подводных лодок-“стратегов” в подводном положении, а также обработки больших массивов информации в соответствующем масштабе времени ${ }^{17}$. Остин Лонг и Брендан Грин из $R A N D$ также указывают на появление дополнительных возможностей по перехвату радиопереговоров между ПГРК и центрами управления СЯС, по размещению на маршрутах движения ПГРК множества датчиков (сейсмических, акустических, инфракрасных и др.), которые могут доставляться в заданный район с помощью БПЛА и передавать информацию через спутники (и используют систему $G P S$ для определения координат и др.) [Long, Green 2015: 64]. Либер и Пресс полагают, что появление у США возможностей нанести первый “обезоруживающий удар” представляет угрозу и для них самих: "Если Америка достигала бы решающей победы в обычной войне", то противник мог бы даже "рассматривать упреждающий удар как способ деэскалации конфликта” [Lieber, Press 2013: 5-6].

Другие американские ученые - Х. Кристенсен, М. Маккинзи и Т. Постал не могут представить себе "ситуацию, при которой компетентный и должным образом информированный президент США мог бы дать приказ о внезапном ядерном ударе по России или Китаю" 18 . Однако тут встает уже другой вопрос об уровне компетентности и информированности главы исполнительной власти в США (равно как и его ближайшего окружения).

Давно стоит также вопрос об участии в “обезоруживающем” ударе со стороны США значительного количества высокоточных дальнобойных средств в неядерном оснащении. Это относится и к потенциальным средствам поражения, которые могут появиться в результате реализации американской концепции “неядерного быстрого глобального удара” (НБГУ). К ним можно отнести в том числе и гиперзвуковые средства поражения ${ }^{19}$.

\footnotetext{
${ }^{17}$ Lieber K. A. Press D. Nuclear Deterrence in the Computer age. The Erosion of Stalemate. - Policy Brief. 16.05.2017. URL: https://www.belfercenter.org/publication/nuclear-deterrence-computer-age-erosionstalemate (accessed 21.03.2018).

${ }^{18}$ Kristensen H.M., McKinzey M., Postal T.A. How US nuclear force modernization is undermining strategic stability. The burst height compensation super-fuze. - The Bulletin of Atomic Scientists. 01.03.2017. URL: https://thebulletin.org/how-us-nuclear-force-modernization-undermining-strategic-stability-burst-heightcompensating-super10578 (accessed 24.04.2018).

19 Резко критикует возможности нанесения “обезоруживающего удара” по российским СЯС за счет средств неядерного быстрого глобального удара ученый и конструктор, академик РАН Ю.С. Соломонов, отметивший, что такой глобальный удар не будет реализован; но фрагменты соответствующих технологий представляют ценность для иных разработок. По его мнению, неядерный быстрый глобальный удар - не первая неосуществимая военная концепция, которая разработана в США. “Американцы в реализации стратегической оборонной инициатива (СОИ) так ничего и не смогли сделать, кроме жульничества, которое было в 1989 г. разоблачено конгрессом США. А СССР
} 
Авторы упомянутого доклада $R A N D$ рекомендуют США пойти на такие меры по ограничению средств НБГУ, чтобы они не рассматривались Россией как угрожающие ее потенциалу ответного ядерного удара. Эксперты делают вывод: “...Решение США ограничить или не развивать средства, которые рассматриваются в России как способные держать под прицелом российские стратегические системы, вероятно, снизит степень озабоченности в России относительно возможности обеспечить второй удар и тем самым обеспечить стратегическую стабильность" [Chivvis et al. 2017: 13].

Некоторые специалисты обращают внимание на то, что К. Либер, Д. Пресс, О. Лонг, Б. Грин и некоторые другие игнорируют факторы, обусловливающие высокую степень неопределенности при нанесении массированных синхронизированных ударов ядерными и неядерными средствами поражения по всем трем компонентам российских СЯС (ракетного “залпа" по нескольким сотням с лишним целей одновременно). Многие эксперты отмечают, что при применении высокоточного оружия (BTO) не учитываются возможности противодействия таким действиям той стороны, которая подвергается нападению ${ }^{20}$. Кроме того, для повышения живучести наземных СЯС могут быть использованы “индивидуальные” средства ПРО.

Натурный эксперимент такого масштаба невозможен, а имитационное моделирование на ЭВМ не способно снизить степень неопределенности до достаточно убеждающего уровня. К тому же при ядерном ударе МБР и БРПЛ будут запускаться не по привычным испытательным траекториям, которые не включают в себя в качестве конечной точки территории другой стороны, а по боевым, существенно отличающимся от испытательных, что также увеличивает неопределенность относительно точности боевого применения и МБР, и БРПЛ, и других ракетных средств, и наносимого противнику ущерба.

Высокой степенью неопределенности характеризуются и действия по “нейтрализации” подводных стратегических ракетоносцев, а также самолетов стратегической авиации с крылатыми ракетами большой дальности, оснащенными ядерными боезарядами.

В ряде американских трудов ставится вопрос о возможной эскалации кризисной ситуации в российско-американских (а в некоторых случаях и китайско-американских) отношениях, которая могла бы подвести к обмену ядерными ударами. Так, в работе Дж. Миллера и Р. Фонтейна речь идет о возможности обмена "ударами" в киберпространстве и о поражении военных космических аппаратов, в результате чего может быть достигнут высокий уровень эскалации конфликта, который поставит стороны в состояние прямой ядерной конфронтации [Miller, Fontaine 2017].

\section{НЕКОТОРЫЕ ИТОГИ}

В совокупности следует говорить об эрозии стратегической стабильности, которая формировалась с конца 1960-х годов, пройдя через ряд “проверок на прочность”. Все вышеупомянутые трансформации создают определенный негативный контекст для решения проблем обеспечения стратегической стабильности как одного из важнейших условий предотвращения ядерной войны с самыми катастрофическими последствиями.

реагировал, принимал это за чистую монету", - подчеркнул Соломонов. См. Разработчик “Булавы”: концепция глобального удара США неосуществима. - РИА Новости. 02.12.2015. Доступ: https://ria. ru/world/20151202/1334161667.html (проверено 8.10.2017).

${ }^{20}$ Disruptive Technologies, Strategic Vulnerability, and the Future of Deterrence. - PIR Press News. 28.06.2017. URL: http://www.pircenter.org/mailouts/view-letter/letter_id/1288/id/3 (accessed 03.06.2018). 
Надежное обеспечение стратегической стабильности - двусторонний, взаимный комплекс действий, динамический процесс (во многом это циклы “действия - контрдействия"). Одна из проблем - недопущение перехода противостояния к наиболее угрожающей ситуации, к потере управляемости обстановкой, особенно к ситуации ядерного конфликта, когда встанет вопрос о применимости ядерного оружия. (“Ядерный конфликт” - кризисная ситуация с вовлечением одного или нескольких обладателей ядерного оружия, в ходе которой напряженность во взаимоотношениях доходит до уровня, когда одна или более сторон начинают использовать в явной форме это оружие в качестве инструмента политического давления. Высшая фаза ядерного конфликта означает его применение в различных масштабах - от единичных и групповых ударов до массированного использования ядерного оружия.)

Необходима максимизация усилий по снижению вероятности возникновения ядерной войны на сравнительно ранних этапах за счет недопущения и ограничения войн меньшего масштаба и просто вооруженных конфликтов, в которые в разных формах могут вовлекаться государства, обладающие ядерным оружием. Для обеспечения стратегической стабильности важны политико-правовые меры, ограничение развития целого ряда технологий, систем вооружений - например, как было в бессрочном советско-американском Договоре об ограничении систем ПРО 1972 г.

Задача поддержания военно-стратегического равновесия с учетом потенциала ракетно-ядерных вооружений не предполагает точного симметричного равенства сил сторон по числу носителей боевых блоков и бомб (совокупному “мегатоннажу") и по суммарному забрасываемому (выводимому) весу. Разрушительная сила ядерного оружия до определенных пределов нивелирует различия в размерах арсеналов сторон, в технических характеристиках отдельных компонентов стратегических сил.

Сейчас крайне важная и актуальная задача заключается в том, чтобы наладить диалог между Россией и США по проблемам стратегической стабильности. Этот диалог - даже в условиях неблагоприятного общего международнополитического контекста - за счет принятия ряда конкретных совместных мер может уменьшить вероятность войны с применением ядерного оружия. Внимание следует сосредоточить на широком спектре политико-военных, оперативно-стратегических и военно-технических вопросов с акцентом на проблемы обеспечения устойчивости стратегического ядерного баланса РФ - США. Предметом особой заботы должны стать и вопросы, связанные с минимизацией шансов эскалации тех или иных конфликтов, и меры по предотвращению случайных, несанкционированных действий.

Арбатов А., Дворкин В. 2011. Стратегическая стабильность до и после холодной войны. - Мировая экономика и международные отношения. № 3. С. 3-11.

Ахромеев С.Ф., Корниенко Г.М. 1992. Глазами маршала и дипломата. Критический взгляд на внешнюю политику СССР до и после 1985 года. М.: Международные отношения. 320 c.

Веселов В.А. 2015. Трансформация параметров стратегической стабильности: роль технологического фактора. - Вестник Московского университета. Серия 25. Международные отношения и мировая политика. Т. 7. № 3. С. 23-56.

Есин В.И. 2015. Политика США в области противоракетной обороны и ее влияние на стратегическую стабильность. - Вестник Московского университета. Серия 25: Международные отношения и мировая политика. Т. 7. № 3. С. 85-114. 
Есин В.И. 2016. Развитие американской и российской систем противоракетной обороны и стратегическая стабильность. - Влияние технологических факторов на параметры угроз национальной безопасности, военных конфликтов и стратегической стабильности. Под ред. А.А. Кокошина. М.: Издательство Московского университета. С. 137-159.

Кокошин А.А., Ларионов В.В. 1987. Курская битва в свете современной оборонительной доктрины. - Мировая экономика и межсдународные отношения. № 8. С. 15-21.

Корниенко Г.М. 2001. “Холодная война”. Свидетельство ее участника. М.: ОЛМАПРЕСС. 504 c.

Нестерчук А.Н., Аксенов О.Ю. 2017. Перспективы развития радиолокационного поля системы предупреждения о ракетном нападении в интересах обеспечения военной безопасности России. - Военная мысль. № 6. С. 43-50.

Chivvis Ch.S., Radin A., Massicot D., Reach C. 2017. Strengthening Strategic Stability with Russia. Santa Monica, CA: RAND Corporation. 24 p. URL: https://www.rand.org/ pubs/perspectives/PE234.html (accessed 25.03.2018)

Dodge M. 2017. Recommendations for the Next Ballistic Missile Defense-and-Defeat Review. - Backgrounder. The Heritage Foundation. No. 3239.7 p.

Kristensen H.M., McKinzey M., Postal Th. A. 2017. How US nuclear force modernization is undermining strategic stability. The burst height compensation super-fuze. - The Bulletin of Atomic Scientists. URL: https://thebulletin.org/how-us-nuclear-force-modernization-undermining-strategic-stability-burst-height-compensating-super10578 (accessed 24.03.2018).

Lieber K., Press D.G. 2013. The New Era of Nuclear Weapons, Deterrence and Conflict. Strategic Studies Quarterly. Spring. 12 p.

Long A., Green B. 2015. Stalking the Secure Second Strike: Intelligence, Counterforce, and Nuclear Strategy. - The Journal of Strategic Studies. Vol. 38. No. 1-2. P. 38-73.

Miller Jr. J., Fontaine R. 2018. Navigating Dangerous Pathways. A Pragmatic Approach to U.S.Russian Relations and Strategic Stability. Harvard Kennedy School, Belfer Center for Science and International Affairs, Center for a New American Security. 32 p.

Miller Jr. J.M., Fontaine R. 2017. A New Era in U.S. Russian Stability. How Changing Geopolitics and Emerging Technologies are Reshaping Pathways to Crisis and Conflict. BCSIA, Harvard Kennedy School, CNAS. 48 p. URL: https://www.cnas.org/publications/reports/a-newera-in-u-s-russian-strategic-stability (accessed 10.03.2018).

Mills M., Toon O., Lee-Taylor J., Robock A. 2014. Multi-Decadal Global Cooling and Unprecedented Ozone Loss Following a Regional Nuclear Conflict. - Earth's Future. Vol. 2. No. 4. P. 161-176.

Robock A., Oman L., Stenchikov G.L. 2007. Nuclear winter revisited with a modern climate model and current nuclear arsenals: Still catastrophic consequences. - Journal of Geophysical Research. Atmospheres. Vol. 112, No. D13107. 14 p. https://doi.org/10.1029/2006JD008235

Robock A., Toon O. 2012. Self-assured destruction: The climate impacts of nuclear war Bulletin of the Atomic Scientists. Vol. 68. No. 5. P. 66-74.

DOI: $10.17976 / \mathrm{jpps} / 2018.04 .02$

\title{
STRATEGIC STABILITY IN A DETERIORATING INTERNATIONAL ENVIRONMENT
}

\author{
A.A. Kokoshin ${ }^{1}$ \\ ${ }^{1}$ Lomonosov Moscow State University. Moscow, Russia
}

KOKOSHIN Andrei Afanasyevich, Dr. Sci. (Hist.), Professor, Member of the Russian Academy of Sciences, member of the Russian Academy of Rocket and Artillery Sciences, Dean of the School of World Politics, Lomonosov Moscow State University. Email: dekanat@fmp.msu.ru

Kokoshin A.A. Strategic Stability in a Deteriorating International Environment. - Polis. Political Studies. 2018. No. 4. P. 7-21. (In Russ.) https://doi.org/10.17976/jpps/2018.04.02 
Abstract. The paper examines the challenges of ensuring strategic stability in a deteriorating international environment characterized by the increasingly conflictual relations between the United States and Russia. The U.S. recent policies increased the likelihood of a direct military confrontation between the two powers and of highly dangerous and rapidly escalating events comparable with the Cuban Missile Crisis. The paper emphasizes the significance of nuclear proliferation challenges and their negative impact on the U.S.-Russia strategic balance. Global strategic stability has been also undermined by a rapid development of various disruptive technologies and weapon systems including cyberwarfare and space warfare capabilities. The erosion of strategic stability takes place against the background of an ongoing complex transition from a unipolar world order to multipolarity. In order to effectively address multidimensional challenges of ensuring and strengthening strategic stability scholars and policymakers alike should focus on the U.S.-Russia strategic nuclear balance while taking into account the impact of the strategic ballistic missile defense systems, strategic non-nuclear weapons and tactical nuclear weapons.

Keywords: strategic stability; escalation; crisis situations; strategic nuclear deterrence; strategic nonnuclear deterrence; arms control; arms reductions.

\section{References}

Akhromeev S.F., Kornienko G.M. Glazami marshala i diplomata. Kriticheskii vzglyad na vneshnyuyu politiku SSSR do i posle 1985 goda [Through the Eyes of the Marshal and Diplomat. A Critical Look at the USSR Foreign Policy before and after 1985]. M.: Mezhdunarodnye otnosheniya. 1992. 320 p. (In Russ.)

Arbatov A., Dvorkin V. Strategic Stability before and after Cold War. - Mirovaya ekonomika i mezhdunarodnye otnosheniya. 2011. No. 3. P. 3-11. (In Russ.)

Chivvis Ch.S., Radin A., Massicot D., Reach C. Strengthening Strategic Stability with Russia. Santa Monica, CA: RAND Corporation. 2017. 24 p. URL: https://www.rand.org/pubs/perspectives/PE234.html (accessed 25.03.2018).

Dodge M. Recommendations for the Next Ballistic Missile Defense-and-Defeat Review. - Backgrounder. The Heritage Foundation. N 3239. August 4. 2017. 7 p.

Esin V.I. U.S. Missile Defense Policy and Its Impact on Strategic Stability. - Moscow University Journal of World Politics. 2015. No. 3. P. 85-114. (In Russ.)

Esin V.I. Razvitie amerikanskoi i rossiiskoi sistem protivoraketnoi oborony i strategicheskaya stabil'nost' [Development of American and Russian Missile Defense Systems and Strategic Stability ]. - Vliyanie tekhnologicheskikh faktorov na parametry ugroz natsional'noi bezopasnosti, voennykh konfliktov i strategicheskoi stabil'nosti (ed. by A.A. Kokoshin) [The Influence of Technological Factors on the Parameters of Threats to National Security, Military Conflicts and Strategic Stability (ed. by A.A. Kokoshin)]. Moscow: Izdatel'stvo Moskovskogo universiteta. 2016. P. 137-159. (In Russ.)

Kokoshin A.A., Larionov V.V. Kursk Battle in the Light of Modern Defensive Doctrine. - Mirovaya ekonomika i mezhdunarodnye otnosheniya. 1987. No. 8. P. 15-21. (In Russ.)

Kornienko G.M. Kholodnaya voina. Svidetel'stvo ee uchastnika [The Cold War. The Evidence of Its Participant]. Moscow: OLMA-PRESS. 2001. 504 p. (In Russ.)

Kristensen H.M., McKinzey M., Postal Th. A. How US Nuclear Force Modernization Is Undermining Strategic Stability. The Burst Height Compensation Super-Fuze. - The Bulletin of Atomic Scientists. 2017. URL: https://thebulletin.org/how-us-nuclear-force-modernization-undermining-strategic-stability-burst-height-compensating-super10578 (accessed 24.03.2018).

Lieber K., Press D.G. The New Era of Nuclear Weapons, Deterrence and Conflict. - Strategic Studies Quarterly. Spring. 2013. 12 p.

Long A., Green B. Stalking the Secure Second Strike: Intelligence, Counterforce, and Nuclear Strategy. The Journal of Strategic Studies. 2015. Vol. 38. No. 1-2. P. 38-73.

Miller Jr. J., Fontaine R. Navigating Dangerous Pathways. A Pragmatic Approach to U.S.-Russian Relations and Strategic Stability. Harvard Kennedy School, Belfer Center for Science and International Affairs, Center for a New American Security. 2018. 32 p.

Miller Jr. J.M., Fontaine R. A New Era in U.S. Russian Stability. How Changing Geopolitics and Emerging Technologies are Reshaping Pathways to Crisis and Conflict. BCSIA, Harvard Kennedy School, CNAS. 2017. 48 p. URL: https:// www.cnas.org/publications/reports/a-new-era-in-u-s-russian-strategic-stability (accessed 10.03.2018).

Mills M., Toon O., Lee-Taylor J., Robock A. Multi-decadal Global Cooling and Unprecedented Ozone Loss Following a Regional Nuclear Conflict. - Earth's Future. 2014. Vol. 2. No. 4. P. 161-176 p.

Nesterchuk A.N., Aksenov O.Yu. Prospects for the Development of the Radar Field of the Russian Missile Attack Warning System in the Interests of Ensuring Russia's Military Security. - Voennaya mysl'. 2017. No. 6. P. 43-50. (In Russ.)

Robock A., Oman L., Stenchikov G.L. Nuclear Winter Revisited with a Modern Climate Model and Current Nuclear Arsenals: Still Catastrophic Consequences. - Journal of Geophysical Research. Atmospheres. 2007. Vol. 112. No. D13107. 14 p. https://doi.org/10.1029/2006JD008235

Robock A., Toon O. Self-Assured Destruction: The Climate Impacts of Nuclear War. - Bulletin of the Atomic Scientists. 2012. Vol. 68. No. 5. P. 66-74.

Veselov V.A. The Role of Technological Factor in Transforming Parameters of Strategic Stability. - Moscow University Journal of World Politics. 2015. No. 3. P. 23-56. (In Russ.) 